KURCHII B. A.

Irpin Economic College, Ukraine, 08200, Irpin, Gagarina str., 9, e-mail: kurchii@ukr.net, (095) 496-92-88

\title{
ON THE NATURE OF NON-PROTEIN RECEPTORS FROM THE CONCEPTUAL POINT OF VIEW. PARADIGM FOR ABSCISIC ACID
}

\begin{abstract}
Abscisic acid (ABA) is a biologically active substance that takes part in the various biochemical and physiological processes in the plants. There is currently limited knowledge about how these biochemical and physiological processes are triggered and regulated by ABA. Dozens of receptors have been described for ABA signaling but there is no any information why does ABA have so many receptors and how they act at the molecular levels. In this connection I would like to stress that not all cell proteins conjugated with ABA necessarily can be represented as hormone-receptors complexes. In this paper I proposed that physiological processes in plants are performed at molecular level by elementary chemical reactions (redox reactions) that trigger the cascade of subsequent reactions and that can be caused by various chemical and physical factors. Gene keys (fragments of polynucleotides, non-protein receptors) and gene locks (start fragment of genes) are also described.

Keywords: abscisic acid, free radicals, receptors, gene keys, gene locks.
\end{abstract}

Abscisic acid as final product from destruction of carotene. ABA is a biologically active substance (BAS) that was discovered during the 1960s [1-3]. Currently a large body of evidence indicates that ABA takes part in the various biochemical and physiological processes, including seed development and germination, seedling growth, stomatal movement, and abiotic stresses, such as drought, high salinity, chilling, and pathogen [4-7]. Also ABA is considered an essential factor in the adaptive response of plants to abiotic stress and is termed a "stress hormone" [8].

The most studied way of ABA formation in the plants during stress action is the cleavage of carotenoids [9]. Analyzing the contradictory literature data of ABA biology in plants and my experimental data I came to the conclusion that ABA is the final stable product of the decomposition of carotene molecules during neutralization of increased amount of free radicals, i.e. during conditions of oxidative stress [10-11].
A number of data indicate that abiotic and biotic stresses are accompanied by activation of oxidative processes [12-14]. The functioning of $\mathrm{ABA}$ in the plantae and the oxidative processes are interrelated. For instance, it has been shown that ROS are required for $A B A$ signal transduction in guard cells [15-16]. At the same time ABA is involved in the ROS production [17].

Why does ABA have so many receptors? There is currently limited knowledge about how these biochemical and physiological processes are triggered and regulated by ABA. It is believed that molecular mechanisms of ABA action both in the regulation of stomata aperture and growth processes are due to the presence of receptors [18]. The structures that are proposed as ABA receptors in the plantae are summarized in table.

From analysis of the data outlined above and in the table, the question arises: "Why does ABA have so many receptors?" Especially since the number of which is constantly increasing. Complicating and confusing the problem is evidence that other plant growth regulators, such as auxin, cytokinin, ethylene, brassinosteroids, jasmones and salicylic acid can also regulate the stomata aperture [29] with the involvement of their own receptors.

Thus, in the context of the foregoing, I came to the conclusion that $\mathrm{ABA}$ does not have a unique function in regulating the stomata aperture or other biochemical reactions. Based on the analysis of the literature data and my experimental data [30], I suggested possible mechanism of $\mathrm{ABA}$ action in plantae in vivo (Fig. 1).

What was disregarded in the receptor theory? In accordance with postulates of receptor theory [31] DNA or RNA primers do not participate in transcription and replication processes of DNA. This is in contradiction with experimental evidences. Experiments in vitro indicate that both DNA transcription and DNA replication do not require protein receptor complexes but instead the short fragments of nucleic acids, called primers [32, 33].

And, what is especially important, A and T

\footnotetext{
${ }^{\text {O }}$ KURCHII B.A.
} 
nucleotides must necessarily be present at both ends in these primers, whereas the $\mathrm{G}$ and $\mathrm{C}$ nucleotides at first glance it appears to be chaotic positioned. In vivo experiments lead to a logical conclusion: RNA polymerase on the way to the chromosome acquires a certain, not a "random" primer, which not only "recognizes" the desired gene, but it also initiates the nucleic acid chain synthesis on the DNA template.

Table. Summary of the structures that are proposed as ABA receptors

\begin{tabular}{|c|c|c|}
\hline Receptors & Plants & References \\
\hline ABAR/CHLH & Arabidopsis & {$[19]$} \\
\hline GCR1 (GPA1, AGB1) & Arabidopsis & {$[20]$} \\
\hline GCR2 & Arabidopsis & {$[21]$} \\
\hline RCARs (14 members) & Arabidopsis & {$[22]$} \\
\hline PP2Cs (80 members) & Arabidopsis & {$[23]$} \\
\hline SnRKs (38 members) & Arabidopsis & {$[24]$} \\
\hline START & Arabidopsis & {$[25]$} \\
\hline PP2Cs (90 members) & Rice & {$[26]$} \\
\hline HbPYL (14 members) & Rubber tree & {$[27]$} \\
\hline PYR/PYL/RCAR (14 receptors) & Tomato & {$[28]$} \\
\hline
\end{tabular}

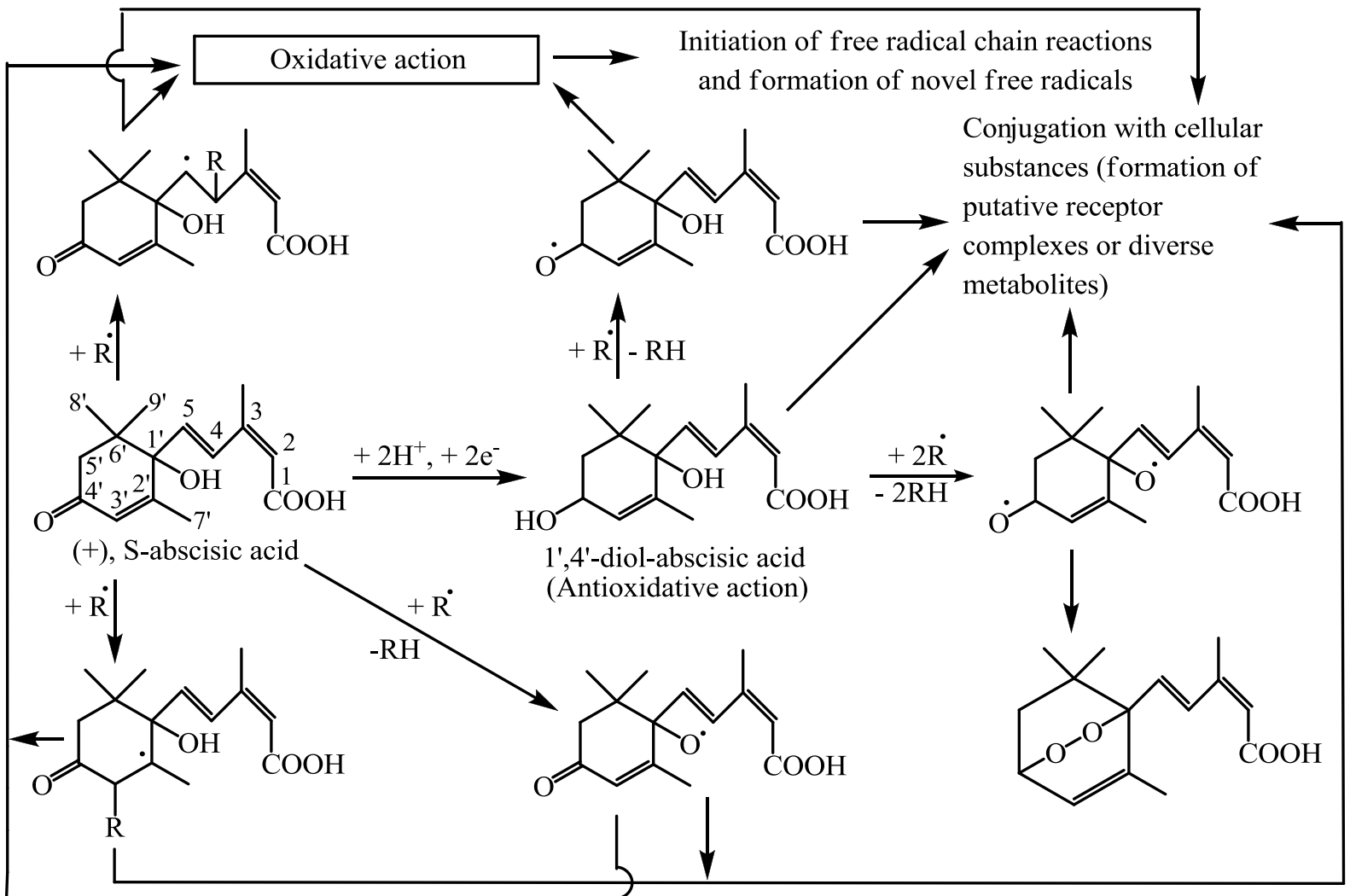

Fig. 1. Proposed pathways for oxidation-reduction and chemical action of ABA in the living systems. All these biochemical actions also will depend on the endogenous level of ABA. Each transformed form of ABA can affect the wide variety biochemical reactions and physiological processes, including the structure and function of membranes, activities of enzymes, activities of antioxidative systems, gene expression (by liberation of gene keys), growth stimulation or inhibition and death of plants. 
An important message from in vitro experiments follows: For the initiation of the nucleic acid synthesis on the DNA matrix of other nucleic acids, not only short fragment of DNA but also microRNA (miRNA), not always as unique nucleotide composition, but with mandatory presence of $\mathrm{A}$ and $\mathrm{T}$ nucleotides can be used as a primer. Unique information also follows from the molecular biology method of the polymerase chain reaction (PCR): DNA primers are required for the reaction to occur, in which $\mathrm{A}$ and $\mathrm{T}$ nucleotides are necessarily present [33].

ABA can really initiate transcription: but how? Earlier I proposed that within the promoter of the gene (or in the cluster of genes) is a spatial structure named as a gene lock $[34,35]$. If there is a gene lock there must be a gene key to it. The base component of the gene lock are TA (or TATA box) nucleotide pairs. These structures are disposed at both ends of the DNA strand. The gene key can be presented in vivo by single-stranded DNA that also has at least two TA nucleotide pairs. Meanwhile, a gene key may present well known the DNA fragment in the PCR analysis named "a primer". The length of both the gene lock and the gene key is diverse in different genes (clusters). Ideally only the GC nucleotide pairs should be disposed between two TA terminal nucleotide pairs in the DNA chain (in the key and the lock). Unfortunately it is not known whether the primer (termed as a receptor or a gene key) is first joined to a gene lock (also termed a gene code) of the gene within the chromosome, or it is first joined to RNA (or DNA) polymerase and subsequently to the gene lock. Thus, each gene (or a cluster) is uniquely labeled. The TA nucleotide pairs from the gene key can form a hydrogen bond with one of the DNA strands. The bond is formed between $\mathrm{O}\left(\mathrm{C}_{2}\right)$ of thymine within the gene lock and $\mathrm{H}\left(\mathrm{C}_{6}\right)$ of adenine within the gene key (Fig. 2).

Primer

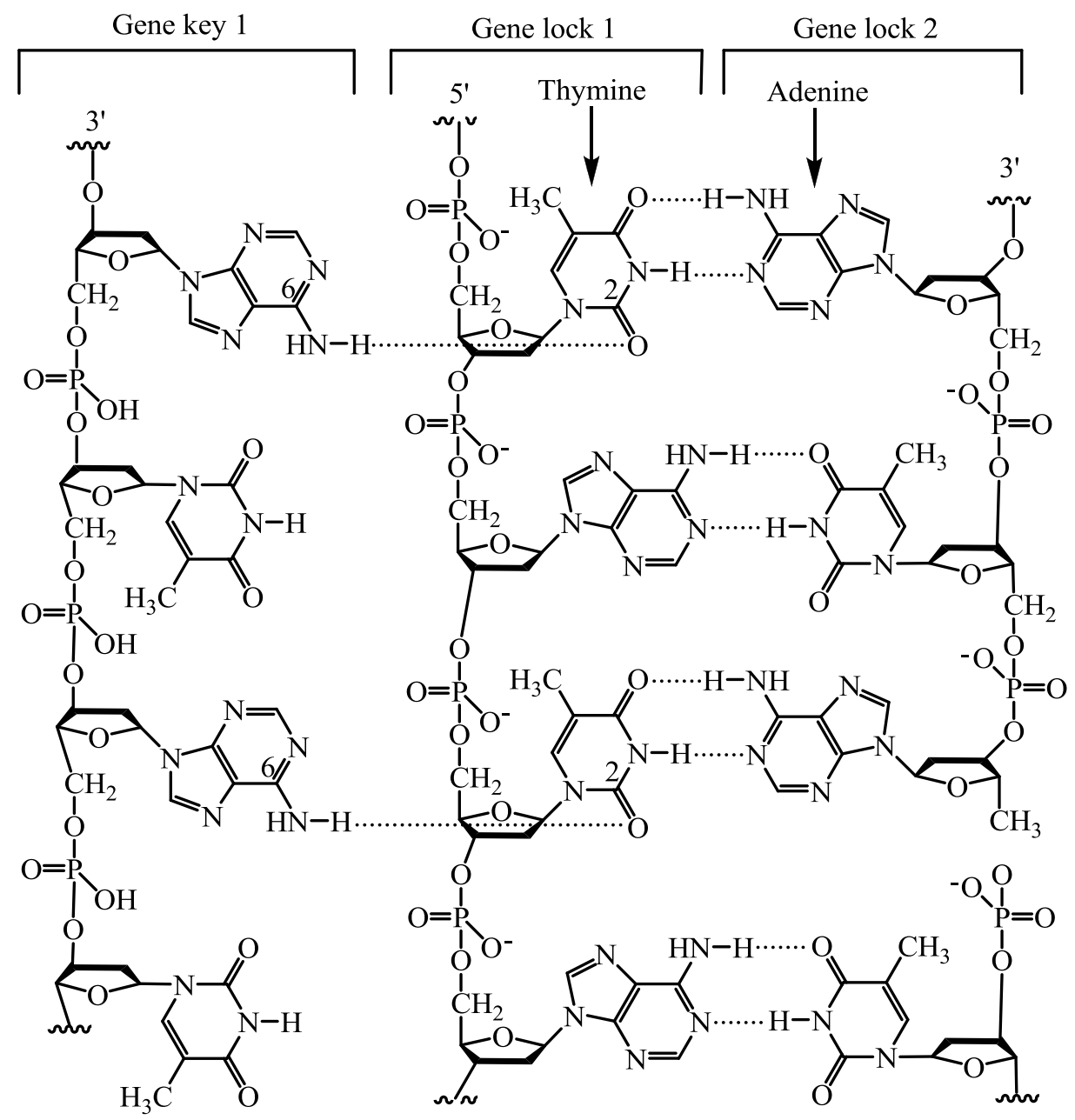

Fig. 2. The mechanism of a gene key (a receptor) anchoring to a gene lock (a promoter of a gene). Such mechanism allows the RNA polymerase to find the desired gene and to start the process of transcription. 
It should be noted that the gene keys may be synthesized preliminary and are reserved within the membranes or other cellular compartments, and they are liberated when this structure are damaged for instance by free radicals (Fig. 3). After the conjugation of RNA (or DNA) polymerase with the gene key this complex seeks the needed gene and the transcription process will be started. Meanwhile, by the absence of the gene key one may explain "the sleepy state" of hundreds or thousands of RNA polymerases in the cell. Another possibility exists when DNA within the promoter is separated under changing in salt concentration into the nucleus during oxidative stress action. This can be possible when the promoter is abolished by A-T nucleotide pairs. In this case RNA polymerase works without any gene key.

Hence, the proposed non-protein structures can effectively function as valid receptors. By syntheses different receptors one will be possible to initiate RNA synthesis from the genes/clusters in vivo. Another way also exists: to study the structures of the gene lock of genes/clusters and on their bases to synthesize the gene key (receptors).

The ongoing transcription processes during the stress response can be enhanced, for example transcription of RNA to synthesize antioxidant substances, or novel transcription processes of genes can be initiated. The newly initiated transcription processes may not depend on the ABA receptors.

\section{Conclusions}

In conclusion, I would like to stress that entities are not to be multiplied without necessity, because the unreal number of receptors, in the long run will discredit the theory of receptors. Not all cell proteins conjugated with $\mathrm{ABA}$, necessarily can be represented as hormone-receptors complex.
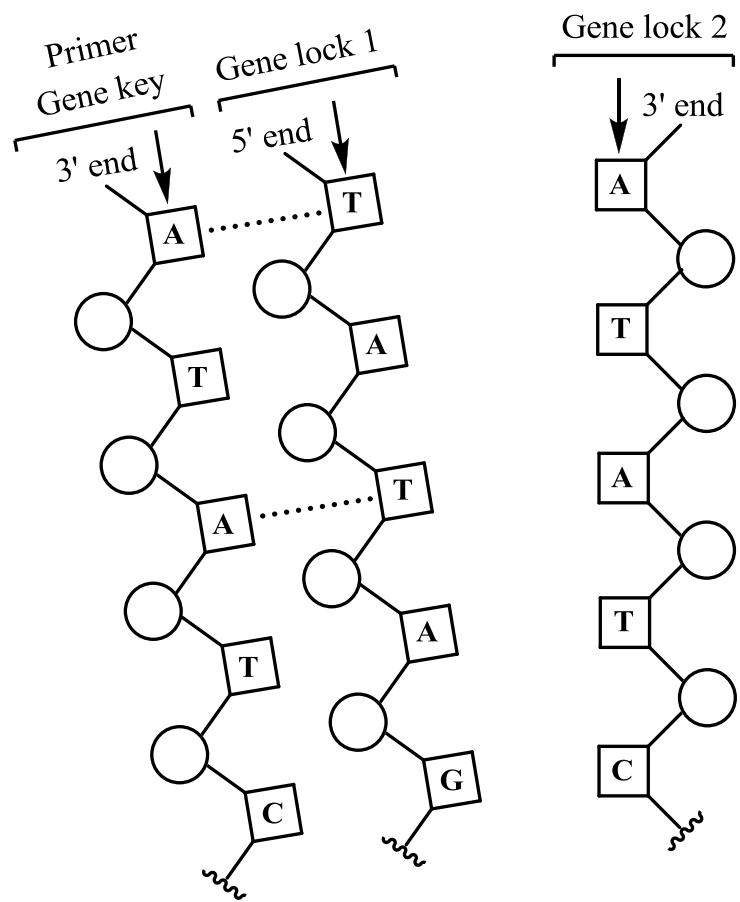

Fig. 3. The mechanism of a gene key (a receptor) anchoring to a gene lock (a promoter of a gene). The interaction between the gene key and the gene lock leads to separation of DNA strands and contributes to the so-called "open complex" formation with the gene lock 2 .

\section{References}

1. Addicott F.T., Lyon G.L., Ohkuma K., Thiessen W.E., Carns H.R., Smith O.E., Cornforth J.W., Milborrow B.V., Ryback G., Wareing P.F. Abscisic acid: a new name for abscisin II (dormin). Science. 1968. Vol. 159. P. 1493.

2. Dörffling K. The discovery of abscisic acid: a retrospect. J. Plant Growth Regul. 2015. Vol. 34. P. 795-808.

3. Milborrow B.V. The identification of $(+)$-abscisin II $[(+)$-dormin] in plants and measurement of its concentrations. Planta. 1967. Vol. 76. P. 93-113.

4. $\quad$ Cutler S.R., Rodriguez P.L., Finkelstein R.R., Abrams S.R. Abscisic acid: Emergence of a core signaling network. Annu. Rev. Plant. Biol. 2010. Vol. 61. P. 651-667. doi: 10.1146/annurev-arplant-042809-112122. 
5. Finkelstein R.R., Gampala S.S., Rock C.D. Abscisic acid signaling in seeds and seedlings. Plant Cell. 2002. Vol. 14 (Suppl.). P. S15-S45. doi: 10.1105/tpc.010441.

6. Himmelbach A., Yang Y., Grill E. Relay and control of abscisic acid signaling. Curr. Opin. Plant Biol. 2003. Vol. 6. P. 470479. doi: 10.1016/S1369-5266(03)00090-6.

7. Trivedi D.K., Gill S.S., Tuteja N. Abscisic acid (ABA): Biosynthesis, regulation, and role in abiotic stress tolerance / Tuteja N., Gill S.S. (Eds). Abiotic Stress Response in Plants, First edition. Weinheim (Germany): Wiley-VCH Verlag GmbH \& Co KGaA, 2016. P. 311-322.

8. Tuteja N. Abscisic acid and abiotic stress signaling. Plant Signal Behav. 2007. Vol. 2. P. 135-138.

9. Endo A., Okamoto M., Koshiba T. ABA biosynthetic and catabolic pathways / Zhang D-P (ed). Abscisic acid: Metabolism, transport and signaling. Dordrecht: Springer Science+Business Media, 2014. P. 21-45.

10. Kurchii B.A. Abscisic acid as a final product of antioxidative metabolism of xanthophylls influenced by diquat. Fisiol. Biokhim. Kul.t Rast. 2000. Vol. 32. P. 334-338.

11. Kurchii B.A. Carotenoids function as quenchers of reactive substances in the photosynthetic machine. 13th Western photosynthesis conference (8-11 January, 2004, Asilomar Conference Center, Pacific Grove, California, USA). P. 23.

12. Luna C.M., Pastori G.M., Driscoll S., Groten K., Bernard S., Foyer C.H. Drought controls on $\mathrm{H}_{2} \mathrm{O}_{2}$ accumulation, catalase (CAT) activity and CAT gene expression in wheat. J. Exp. Bot. 2005. Vol. 56. P. 417-423. doi: 10.1093/jxb/eri039.

13. Mittler R., Blumwald E. The roles of ROS and ABA in systemic acquired acclimation. Plant Cell. 2015. Vol. 27. P. 64-70. doi: $10.1105 /$ tpc.114.133090.

14. Zhang F., Wang Y., Yang Y., Wu H., Wang D., Liu J. Involvement of hydrogen peroxide and nitric oxide in salt resistance in the calluses from Populus euphratica. Plant Cell Environ. 2007. Vol. 30. P. 775-785. doi: 10.1111/j.1365-3040.2007.01667.x.

15. Guan L.M., Zhao J., Scandalios J.G. Cis-elements and trans-factors that regulate expression of the maize Cat1 antioxidant gene in response to ABA and osmotic stress: $\mathrm{H}_{2} \mathrm{O}_{2}$ is the likely intermediary signaling molecule for the response. Plant $J$. 2000. Vol. 22. P. 87-95.

16. Kwak J.M., Mori I.C., Pei Z.M., Leonhardt N., Torres M.A., Dangl J.L., Bloom R.E., Bodde S., Jones J.D.G., Schroeder J.I. NADPH oxidase AtrbohD and AtrbohF genes function in ROS-dependent ABA signaling in Arabidopsis. EMBO J. 2003. Vol. 22. P. 2623-2633. doi: 10.1093/emboj/cdg277.

17. Pornsiriwong W., Estavillo G.M., Chan K.X., Tee E.E. A chloroplast retrograde signal, 3'-phosphoadenosine 5'-phosphate, acts as a secondary messenger in abscisic acid signaling in stomatal closure and germination. eLife. 2017. Vol. 6. P. e23361.

18. Samarah N.H. Understanding how plants respond to drought stress at the molecular and whole plant levels / Hossain M.A., Wani S.H., Bhattacharjee S., Burritt D.J., Tran L-S.P. (Eds). Drought stress tolerance in plants. Vol. 2. Springer International Publishing Switzerland, 2016. P. 1-38.

19. Shen Y-Y., Wang X-F., Wu F-Q., Du S-Y., Cao Z., Shang Y., Wang X-L., Peng C-C., Yu X-C., Zhu S-Y., Fan R-C., Xu1 Y H., Zhang D-P. The Mg-chelatase H subunit is an abscisic acid receptor. Nature. 2006. Vol. 443. P. 823-826. doi: 10.1038/nature05176.

20. Pandey S., Chen J.G., Jones A.M., Assmann S.M. G-protein complex mutants are hypersensitive to abscisic acid regulation of germination and postgermination development. Plant Physiol. 2006. Vol. 141. P. 243-256. doi: 10.1104/pp.106.079038.

21. Liu X., Yue Y., Li B., Nie Y., Li W., Wu W-H., Ma L. A G protein-coupled receptor is a plasma membrane receptor for the plant hormone abscisic acid. Science. 2007. Vol. 315. P. 1712-1716. doi: 10.1126/science.1135882.

22. Ma Y., Szostkiewicz I., Korte A., Moes D., Yang Y., Christmann A., Grill E. Regulators of PP2C phosphatase activity function as abscisic acid sensors. Science. 2009. Vol. 324. P. 1064-1068. doi: 10.1126/science.1172408.

23. Xue T., Wang D., Zhang S., Ehlting J., Ni F., Jakab S., Zheng C., Zhong Y. Genome-wide and expression analysis of protein phosphatase 2C in rice and Arabidopsis. BMC Genomics. 2008. Vol. 9. P. 550. doi.org/10.1186/1471-2164-9-550.

24. Hrabak E.M., Chan C.W.M., Gribskov M., Harper J.F., Choi J.H., Halford N., Kudla J., Luan S., Nimmo H.G., Sussman M.R., Thomas M., Walker-Simmons K., Zhu J-K., Harmon A.C. Arabidopsis CDPK-SnRK superfamily of protein kinases. Plant Physiol. 2003. Vol. 132. P. 666-680. doi: 10.1104/pp.102.011999.

25. Park S-Y., Fung P., Nishimura N., Jensen D.R., Fujii H., Zhao Y., Lumba S., Santiago J., Rodrigues A.,. Chow T-F., Alfred S.E., Bonetta D., Finkelstein R., Provart N.J., Desveaux D., Rodriguez P., McCourt P., Zhu J-K., Schroeder J.I., Volkman B.F., Cutler S.R. Abscisic acid inhibits type 2C protein phosphatases via the PYR/PYL family of START proteins. Science. 2009. Vol. 324. P. 1068-1071. doi: 10.1126/science.1173041.

26. Singh A., Giri J., Kapoor S., Tyagi A.K., Pandey G.K. Protein phosphatase complement in rice: genome-wide identification and transcriptional analysis under abiotic stress conditions and reproductive development. BMC Genomics. 2010. Vol. 11. P. 435.

27. Guo D., Zhou Y., Li H-L., Zhu J-H., Wang Y., Chen X-T., Peng S-Q. Identification and characterization of the abscisic acid (ABA) receptor gene family and its expression in response to hormones in the rubber tree. Sci. Rep. 2017. Vol. 7. P. 45157. doi: $10.1038 /$ srep45157.

28. González-Guzmán M., Rodríguez L., Lorenzo-Orts L., Pons C., Sarrión-Perdigones A., Fernández M.A., Peirats-Llobet M., Forment J., Moreno-Alvero M., Cutler S.R., Albert A., Granell A., Rodríguez P.L. Tomato PYR/PYL/RCAR abscisic acid receptors show high expression in root, differential sensitivity to the abscisic acid agonist quinabactin, and the capability to enhance plant drought resistance. J. Exp. Bot. 2014. Vol. 65. P. 4451-4464. doi: 10.1093/jxb/eru219.

29. Acharya B.R., Assmann S.M. Hormone interactions in stomatal function. Plant Mol. Biol. 2009. Vol. 69. P. 451-462. doi: 10.1007/s11103-008-9427-0.

30. Kurchii B.A. A study of the antioxidative activity of abscisic acid / 10th FESPP Congress "From molecular mechanism to the plant: An integrated approach", September 9-13, 1996, Florence (Italy). Plant Physiol. Biochem. (Special issue). 1996. P. 295.

31. Vidhyasekaran P. Plant hormone signaling systems in plant innate immunity. Dordrecht: Springer Science+Business Media, 2015. $473 \mathrm{p}$. 
32. Vatolin S., Weil R.J. Extension of endogenous primers as a tool to detect micro-RNA targets / Colowick S.P., Kaplan N.O. (Eds) Methods in enzymology. 2008. Vol. 449. P. 357-371.

33. Park D.J. (Ed) PCR Protocols. Third edition. Heidelberg: Springer Science+Business Media, LLC, 2011.

34. Kurchii B.A. The molecular mechanism of hydrogen bond formation between T-A base pairs within a promoter and a sigma factor. Factors of experimental evolution of organisms. Kiev: Logos Publisher, 2009. Vol. 7. P. 78-82.

35. Kurchii B.A. The relationship among biological membranes and signaling mediators. II. How do the receptors find and identify their targets? Ukr. Bioorg. Acta. 2010. Vol. 8 (N2). P. 31-35.

\section{КУРЧІЙ Б. О.}

Ірпінський економічний коледж, Україна, 08200, м. Ірпінь, вул. Гагаріна, 9, e-mail: kurchii@ ukr.net

\section{ПРО ПРИРОДУ НЕБЛКОВИХ РЕЦЕПТОРІВ 3 КОНЦЕПТУАЛЬНОЇ ТОЧКИ ЗОРУ. ПАРАДИГМА ДЛЯ АБСЦИЗОВОї КИСЛОТИ}

Абсцизова кислота (АБК) - біологічно активна сполука, яка бере участь у різних біохімічних і фізіологічних процесах рослин. Дані про те, як АБК запускає і регулює ці біохімічні і фізіологічні процеси на сьогодні обмежені. Десятки рецепторів описано для сигналізації АБК, проте інформація, чому так багато рецепторів існує і як вони діють на молекулярному рівні, відсутня. Тому, всі сполучені з АБК білки можуть бути гормонрецепторними комплексами. У цій статті подано інформацію про те, що фізіологічні процеси у рослинах на молекулярному рівні, здійснюючись як елементарні хімічні реакції (редокс реакції), запускають каскади наступних реакцій, котрі також можуть запускатись різними хімічними і фізичними факторами. Генні ключі (фрагменти полінуклеотидів, небілкові рецептори) і генні замки (стартові фрагменти генів) також описано. Ключові слова: абсцизова кислота, вільні радикали, рецептори, генні ключі, генні замки. 